\title{
Batı Toplumları Açısından Din Suç İlişkisine Ekolojik Bakış Açısı: Ahlaki Topluluk Tezi
}

\author{
Ecological Perspective on the Relationship between Religion and Crime in terms \\ of Western Societies: The Moral Community Thesis
}

Öz

Tarih boyunca özellikle sosyolojik düzeyde din ve suç üzerine birçok araştırma yapılmıştır. Yapılan araştırmalar çoğunlukla sosyal kontrol, sosyal öğrenme, rasyonel seçim teorisi, kontrol kuramı kullanılarak test edilmiştir. Ancak dinin suç davranışı üzerindeki sosyal etkisinin ekolojik incelemesi akademisyenler tarafindan nispeten ihmal edilmiştir. Ahlaki topluluk tezine (moral community thesis) göre muhafazakâr toplumlarda bireylerin suç işleme oranı seküler toplumlara göre azdır ya da hiç yoktur. Bireyin suç/sosyal sapma davranışlarına yönelmesi çevrenin bireyin davranışlar üzerindeki olumlu ya da olumsuz etkisi ile ortaya çımaktadır.

Türkiye'de ahlaki topluluk tezi ile ilgili çalısma yok denecek kadar azdır. Dinin suç üzerindeki etkisini ortaya koyan çalı̧malar çoğunlukla Amerika Bileşik Devletleri, Avrupa ve Çin'de uygulanmıştır. Türkiye'de ise dinin suç üzerindeki etkisini ortaya koyan birçok çalışma yapılmıştır ancak ahlaki topluluk tezini test eden çalışmalar yok denecek kadar azdır. Bu çalısmanın amacı Ahlaki topluluk tezinin ne olduğunu ve literatürdeki yerini vurgulayarak, bundan sonra Türkiye'de din suç ilişkisi üzerine yapılacak çalışmalara yeni bir bakış açısı kazandırmaktır. Bu çalışma ile geleneksel literatür taraması kullanılmış ve konuya ilişkin çalı̧̧malar ve elde edilen bulgulara odaklanılmıştır. Elde edilen sonuçlar değerlendirildiğinde genel olarak örneklemin çoğunlukla yetişkinler üzerine uygulandığını ve ahlaki topluluk tezinin destek bulduğunu ortaya koymuştur. Bu alanda yapılan çalışmaların son yıllarda daha da arttı̆̆ı görülmüşsür.

\section{Abstract}

Throughout history, there have been many studies on religion and crime, especially at the sociological level. Researches have been mostly tested using social control, social learning, rational choice theory, control theory.

\author{
Fatma Takmaz Demirel \\ Dr. Yeşilyurt SYDV \\ ftm.hkmhn@gmail.com \\ Orcid No: https://orcid.org/0000-0003- \\ 3447-3394
}

Article Type / Makale Türü

Research Article / Araştırma Makalesi

Anahtar Kelimeler

Din, Suç/Sosyal Sapma, Ahlaki Topluluk Tezi

\begin{abstract}
Keywords
Religion, Cirime/Social Deviation, Moral Community Thesis

Bilgilendirme

Bu çalışma 14-18 Nisan 2021 tarihlerinde gerçekleştirilen Muğla Sitkı Koçman Üniversitesinde gerçekleştirilen 4. Uluslararası Felsefe Eğitim Sanat ve Bilim Tarihi Sempozyumu'nda Sözlü Bildiri olarak sunulmuştur.
\end{abstract}

JEL Codes: Z100, Z190, Z12

Submitted: $20 / 06 / 2021$ Accepted: $\quad 10 / 11 / 2021$ However, the ecological study of the social impact of religion on criminal behavior has been relatively neglected by academics. According to the moral community thesis, individuals commit less or no crime in conservative societies than in secular societies. Individual front towards criminal /social deviation behaviors emerges with the positive or negative effect of the environment on the individual's behavior.

There are hardly any studies on the moral community thesis in Turkey. Studies revealing the effect of religion on crime have mostly been applied in the United States, Europe and China, and different results have been obtained. In Turkey, there have been many studies that reveal the effect of religion on crime but only one study has been conducted to test the moral community thesis. The aim of this study is to emphasize what the moral community thesis is and its place in the literature. After that, it is to bring a new perspective to the studies to be done on the religion-crime relationship in Turkey. In this study, traditional literature review was used and focused on the studies and the findings obtained. The results obtained revealed that the sample was mostly applied to adults and the moral community thesis was supported. It has been observed that studies in this field have increased in recent years.

\section{Giriş}

Suç kavramı tarih içerisinde oldukça farklı şekillerde ifade edilmiş, yorumlanmış ve kurama dönüştürülmüştür. Suç kavramını ele alan birçok disiplin bulunmaktadır. Her disiplin kendi alanı içinde suç olgusunu farklı yorumlamıştır. Durkheim suç olgusunu toplumsal yapı içerisinde sistemden kopma durumu olarak tanımlamıştır. Suç/sosyal sapmanın toplumdaki sadece bir grup tarafından değil her kesim tarafından işlenebileceğini ifade etmiştir (Durkheim, 2014). Suç davranışı 
toplumda yazılı kurallara uymama veya ihlal etme durumunda ortaya çıkmaktadır. Sapma davranışı ise bireylerin içinde bulunduğu toplumun norm ve değerlerine uymama ve aykırı davranma ile ortaya çıkmaktadır. Toplumun yazılı kurallarına uymama suç fiilini doğururken, toplumun norm ve değerlerine uymama ise sapmayı doğurmaktadır (Yücel 2004: 22). Sapma kültürel değerlerin belirlediği örf, adet, gelenek, göreneklere uymama davranışı ile ortaya çıkmaktadır (İçli, 2007). Fichter sapmayı olumlu ve olumsuz olarak ikiye ayırmaktadır. Olumlu sapma toplumda kabul edilen ideal davranış kalıpları olarak ifade edilirken, olumsuz sapma ise kabul edilmeyen, toplum tarafından aşağı ve yetersiz görülen davranış kalıpları olarak ifade edilmektedir (Fichter, 2002: 194). Literatürde sapma kavramının tanımlanması için üç önemli unsur öne çıkmaktadır. İlki toplumsal beklentilere karşılık verilmemesi, ikincisi toplumsal normların ihlali, üçüncüsü ise toplumsal normlara aykırılık teşkil etmesidir (Güçlü ve Akbaş, 2016:25).

Her suç sapma değildir, her sapma da suç olarak kabul edilemez (Güçlü ve Akbaş, 2016:27). Hatta suç ve sapmanın niteliği toplumdan topluma ve zamandan zamana değişiklik göstermektedir. Toplumun yazılı olmayan kurallarına uygun olmayan tarzda davranışlar (kopya çekme, intihara niyet etme, alkol kullanma vb.) sapma olarak kabul edilirken bir suç davranışı olarak değerlendirilmemektedir (Güneş, 2018:12). Yine her suç davranışı problem olarak kabul edilirken, her problemli davranış ise suç olarak kabul edilemez. Suç ve sapma arasında kesişim kümesi ne kadar büyük olursa toplumun yazılı ve sözlü kuralları arasındaki fark da o kadar az olmaktadır. Suç ve sapma olgusunun doğasının karmaşık olması sosyal bir etkileşim sonucu ortaya çıkması, toplumdan topluma çeşitlilik göstermesi ve çok çeşitli toplumsal faktörlerin (yoksulluk, toplumsal sınıf, işsizlik ve göç) etkili olması sosyolojiyi sapkın davranışları incelemede en önemli aktör haline getirmiştir (Güçlü ve Akbaş, 2016:23).

Din ise geçmişten günümüze toplumun şekillenmesinde önemli rol oynamış ve bireylerin toplum içinde görev ve sorumluluklarını düzenleyen işlevsel bir konuma sahip olmuştur. Din yasalara uyma davranışını teşvik etmek için önemli bir sosyalleşme aracıdır. Durkheim'e (2014) göre din toplum yararına hizmet etmektedir. Durkheim dini örgütlerin bireyler üzerinde etkin rol oynadığını vurgulamıştır. Sosyal yapı ve düzensizlik Durkheim'e göre anomik durumları meydana getirmiştir. İntihar (1879) adlı eserinde toplumun anomi durumu olan ve o dönemde gittikçe artan intihar eylemlerini araştırmış, toplumsal yapıdaki sapma eyleminin temel sebeplerini bulmaya çalışmıştır. Avrupa'da Katolik bölge ve Protestanların bulunduğu bölgeler arasında intihar oranlarında çok önemli farklılıklar keşfetmiş ve açıklamıştır. Bu noktada Durkheim dinin toplumun bir yansıması olduğunu iddia etmiştir. Durkheim Marx ile yakın düşünceye sahiptir ancak Marx, dinin halkın bir afyonu olduğunu söylerken, Durkheim, dinin taraftarlarını "tek bir ahlâki topluluk (single moral community)" adı altında birleştirme gücüne sahip olduğunu kabul etmiştir (Stark ve Bainbridge, 1996:15). Durkheim 1915 yılında "Dini Yaşamın Temel İlkeleri (The Elementary Forms of Religious Life) adlı eserinde dini ibadetin nesnesinin gerçekte toplum olduğunu, bireyler toplumsal bir bütün içinde kendi değerlerinden uzak dini törenler gerçekleştirdiklerini ifade etmiştir (akt. Stark ve Bainbridge, 1996:53).

Smith (2003)'e göre, Durkheim' den bu yana sosyologlar dinin normatif kültürün temel unsuru olduğunu ve birey, topluluk ve toplum üzerinde potansiyel motivasyon ve kontrol mekanizması olduğunu kabul etmişlerdir. Din diğer kültürel güçlerden göreceli olarak farklıdır. Din ahlaki davranış normlarına yoğun bir şekilde odaklanmaktadır. Bireylere, gruplara, topluluklara ve toplumlara farklı ahlaki anlatılar ve kültürel anlamlar sağlamaktadır (akt. Ulmer and Harris, 2014:4).

Dini değerlere sahip bireyler yaşadıkları sosyal çevre, arkadaş ortamı ve aile ortamından etkilenmektedirler. Sosyal çevrenin muhafazakâr olması bireyin kendi kendini kontrol etmesi ve kurallara uyması konusunda baskın rol oynayacaktır. Bireyin dış kontrol mekanizması ne kadar fazla ise birey suç/ sosyal sapma davranışına karşı eğilimi o kadar az olmaktadır. Sosyal denetim bireyin suç davranışları üzerinde azaltıcı yönde etkiye sahiptir. Dinin suç üzerindeki etkisinin ne olduğunu tespit etmeye çalışan araştırmacılar farklı yerlerde farklı sonuçlar elde etmişlerdir. Bu bağlamda, Hirshi ve Stark' in (1969) "Hellfire and Delinquency" çalışması din-suç ilişkili çalışmalar arasında ilk olma özelliğini taşımaktadır. Hirschi ve Stark dindarlığın suç ve sapma üzerindeki etkisinin ne olduğunu tespit etmek için California'nın Western Contra Costa şehrinde saha çalışması 
yapmışlardır. Bu çalışma ile ortaokul ve lise öğrencileri arasından rastgele seçilen 4.077 kişiye anket uygulayarak "cehennem ateşi" hipotezini test etmeye çalışmışlardır. Elde edilen sonuçlar dindarlık ve suçluluk arasında ilişkinin olmadığını göstermiştir. Bu çalışma ile "Şeytan'a ve ölümden sonraki hayata inanan öğrenciler, doğaüstü bir dünyaya inanmayan öğrenciler kadar suçlu eylemlerde bulunma olasılıklarının yüksek olduğu" tespit edilmiştir (1969: 210). Bu çalışma dindarlık ve sapkınlık arasındaki ilişkiyi ele alan sonraki araştırmalar üzerinde derin bir etki oluşturmuştur. Hirschi ve Stark' in araştırmasının sonuçları çok şaşırtıcı olduğu için, bu makalenin hemen ardından yapılan araştırmalar, Hirschi ve Stark'ın çalışmasının bire bir aynısını farklı bölgelerde uygulamaya yönelik olmuştur. Bu anlamda ilk çalışma Burkett ve White (1974) tarafından Kuzeybatı Pasifik'te yapılmıştır. Bu çalışma ile 855 lise öğrencisine anket uygulanmıştır. Elde edilen sonuçlar ise Hirschi ve Stark (1969) çalışmasından elde edilen sonucun aksine dindarlık ile alkol ve esrar gibi maddelerin kullanımı arasında negatif ilişki tespit edilmiştir. Hirschi ve Stark'ın çalışmasının ardından yapılan ikinci çalışma Higgins ve Albrecht (1977) tarafından Atlanta' da yapılmıştır. Bu çalışma altı lisede öğrenim gören onuncu sınıf öğrencileri olmak üzere toplam 1.410 öğrenciden oluşmaktadır. Elde edilen sonuçlara göre, dindarlık ve suçluluk arasında ters bir ilişki olduğu tespit edilmiştir. Üçüncü çalışma ise Jensen ve Erickson (1979) tarafından Arizona'da yapılmıştır. Bu çalışma ile 3.268 lise öğrencisine anket uygulanmıştır. Elde edilen sonuçlara göre dindarlık ve suçluluk arasında negatif ilişkinin olduğunu göstermiştir. Benzer şekilde ailevi ilişkilerin gücü ile suçluluk arasında da negatif ilişki olduğu tespit edilmiştir (Stark, 1996: 163-164).

Dinin suç üzerindeki etkisini araştıran bu ve bundan sonraki araştırmalar benzer araştırmayı farklı yerlerde yeniden test etmişler ve birçok kuram geliştirmişlerdir. Bu kuramların en önemlileri arasında gösterilecek olan ahlaki topluluk tezi toplumu bireysel değil ekolojik düzeyde incelemek gerektiğini ileri sürmüştür. İçinde yaşanılan çevre bireyin davranışlarında önemli rol oynamaktadır. Bireyin suç/sapma davranışlarına yönelmesi çevrenin bireyin davranışları üzerindeki olumlu ya da olumsuz etkisi ile ortaya çıkmaktadır. Suç ve sosyal sapmanın en önemli etkisi toplumda meydana gelen çözülmedir. Sosyal çözülme olarak adlandırılan bu kavram maddi ve manevi değerlerin birbirini tamamlayamaması sonucu ortaya çıkmaktadır. Modernleşmenin getirdiği ekonomik ve sosyal değişme birbirine paralel olarak gelişmediği için toplumda bazı boşluklar oluşmaktadır. Maddi ve manevi değerlerdeki değişim oranları eşit olmadığı durumda sosyal bozulmalar meydana gelmektedir. Geleneksel yapılardaki geniş aile, arkadaş grubu modern yapılarda yerini bireysel çıkarların ve rekabetin ön planda olduğu ilişkilere bırakmıştır. Bireysel ve toplumsal hedefler arasındaki fark oldukça artmıştır. Bireyler toplumun bir parçası haline gelmiştir. Toplumsal kurallar normlarla değil hukuki yaptırımlarla sağlanmaktadır. Bireyin sahip olduğu normlar ise etki derecesini kaybetmiştir. Birey üzerinde toplumsal baskı ortadan kalkmıştır ancak bu durum özgürleştiği anlamına gelmemektedir. Çünkü bireyin davranışları ve düşüncesi modernleşmenin getirdiği yaptırımlarla şekillenmektedir. Dolayısıyla birey geleneksel modern ikilemi arasında ve modernleşmenin getirdiği hayat tarzı ile büyük bir değişime uğramıştır. Bu değişim başarılı bir şekilde toplumun tüm kurumlarında uygulanmazsa arada oluşan boşluk anomiyi oluşturacaktır. Toplumsal memnuniyetsizlikler gittikçe artacağından bireyler sapma ve suç davranışlarına daha fazla yöneleceklerdir. Toplumda oluşan bu boşluğu doldurmak için din kurumu devreye girmektedir. Bireylerin çatışmadan uzaklaşmasını, uyumlu ve dengeli olmayı öğütlemektedir. Böylece ortaya çıkan kutuplaşma ve bireysel memnuniyetsizlikler din ile ortadan kalkmaktadır. Dolayısıyla dinin toplumda oldukça etkin bir rol üstlendiğin söylemek gerekir.

Bu çalışma ile suçu önlemede önemli bir etkiye sahip olan ahlaki topluluk tezinin ne olduğu ifade edilmeye çalışılmıştır. Bu noktada ilk olarak ahlaki topluluk tezi ile yakın ilişkide olan kuramlardan kısaca bahsedilmiştir. Ardından ahlaki topluluk tezinin ne olduğu anlatılmış ve dünya da ve Türkiye' de ahlaki topluluk tezi kullanılarak yapılan çalışmaların literatür taraması yapılmıştır. $\mathrm{Bu}$ çalışma ile geleneksel literatür taraması tekniği kullanılarak sadece konuya ilişkin çalışmalara ve bulgulara odaklanılmıştır. Literatür taraması bir konu üzerinde araştırma yapma veya literatürün değerlendirilmesini tasvir eden açılamadır. Literatür taraması bir problemi çözmek, bir konuyu anlamak ve bir ilişkiyi incelemek için çalışmaların ortak oktasını göstermek amacıyla çok sayıda çalışmaların analizi ve sentezini içermektedir (akt. Özbay 2021:86). 


\section{Dinin Suç Üzerindeki Etkisini Ele Alan Bazı Kuramlar}

Yaklaşık 1980 sonrası dönemde dindarlık ve sapkınlık arasındaki ilişki üzerine araştırmacılar, dindarlığın sapmayı neden engellen bir faktör olduğunu açıklamak veya iki değişken arasındaki ilişkinin doğasını ele almak için birçok kuram geliştirilmiştir. Bu kuramlardan bazıları ahlaki topluluk tezi ile yakından ilişkilidir. Bu kuramların temel özelliklerini ve sahip olduğu kavramları bilmek ahlaki topluluk tezinin ne olduğunu anlamak açısından bize yol gösterici olacaktır. Ahlaki topluluk tezinin bu kuramlarla farklı yönleri olduğu gibi ortak yönleri de bulunmaktadır. Hatta bu kuramlardan bazıları ahlaki topluluk tezinin ortaya çıkmasına vesile olmuştur. Durkheim, Hirschi ve Stark'ın Sosyal Kontrol Teorileri, Sutherland'ın Ayırıcı Birliktelikler Teorisi bu kuramlar arasındadır. Ayrıca Durkheim'in anomi teorisi de ahlaki topluluk tezi ile yakından ilişkilidir. Chicago Üniversitesi'nin 1930-40'lardan itibaren toplum ekolojisi üzerine yaptığ 1 araştırmalar ile ortaya konulan ekolojik kuram da yine ahlaki topluluk tezinin ortaya çıkmasında önemli rol oynamıştır.

Durkheim tarafından ilk olarak ortaya atılan ve Hirschi tarafından formüle edilmiş olan sosyal kontrol teorisinde sosyal sapmanın bireyin topluma olan bağının zayıflaması ile ortaya çıktığı ifade edilmektedir (1969:16). Bu kuram Hobbes'un ünlü sözü "insan insanın kurdudur" mottosunu ilke edinmiştir ve herkesin suç işlemeye meyilli olduğunu vurgulamaktadır. Bu kuram insanlar "neden suç işlemektedir" ifadesi yerine "neden suç işlemez" ifadesi üzerine odaklanmaktadır (Özbay, 2020:71). Bu kuram ile sapkın davranışlar üzerinde kısıtlama dört kritik bağlanma ile açıklanmıştır. Bunlar bağlılık (attachment), taahhüt (commitment), katılım (involvement) ve inanç (belief)'tır (Benda ve Corwyn, 1997: 83). Bağl1lık bireylerin topluma ne derece entegre olduğunu gösteren bir kavramdır. Ebeveynlere bağlılı̆̆ın zayıf olması sapkın davranışların ortaya çıkmasında etkin bir rol oynamaktadır. Bireyi oyalayacak ve onun suç eyleminden uzaklaşmasını sağlayacak bir toplumsal etkinliğe ya da taahhüte ihtiyaç vardır. Zamanını ve emeğini belli bir amaç için kullanan bireyler hedefe odaklandıklarından suç davranışını gerçekleştirme ihtimalleri düşüktür. Bazı çalışmalar suçlu eylemleri teşvik etmek için doğal dürtüler üzerinde kısıtlama eksikliğine ek olarak motivasyona ihtiyaç olduğunu ortaya koymaktadır (1997: 82). Dini faaliyetlere katılımı yüksek olan bireyler suç eylemini azaltıcı değer ve normlara göre sosyalleşirler. Sadece dini içerikli aktiviteler değil sosyal aktiviteler de bireyleri suç işlemekten alıkoymak için yeterli nedenlerdendir. (Ellis ve Peterson, 1996: 765).

Sutherland (1947) ayırıcı birliktelikler teorisi ile suçun bireysel ve grupsal oranlarındaki farklılıklarını formüle etmeye çalışmıştır. Bu teori "suç davranışı öğrenilir, suç etkileşimin yan ürünüdür, öğrenme yakın gruplar içinde olur" önermeleri olmak üzere toplam dokuz maddeden oluşmaktadır. Bu teori ile kanun ve normu ihlal eden tutumların fazla olduğu yerde çocuklar daha fazla suça meyilli olmaktadırlar. Toplumda bazı insanlar kanunlara uyar, bazıları ise kanunlara uymanın gereksiz olduğunu düşünürler. Kanunları çiğneyen tanımlarla daha fazla karşılaşmak ve kanunlara uymanın gereksiz olduğunu düşünen bireylerle aynı mekânı paylaşmak suça yönelimi artırmaktadır. Bu durumu ayırıcı birliktelikler teorisinin ana prensibidir (Özbay, 2020:58-60). Bu teoride bireyin model aldığı kişi ya da sahip olduğu ortam davranışlarında etkin rol oynamaktadır. Yapılan birçok çalışma ergenlik döneminde, akranların ebeveynlere oranla gençler üzerinde daha fazla etkiye sahip olduklarını göstermiştir. Akran etkisi dindarlığın yanı sıra suçluluğu da teşvik edebilir veya caydırabilir (Burkett, 1993; Burkett ve Warren, 1987; Turner ve Willis, 1979). Türkiye' de Özbay'ın (2016) öğrenme teorisi ile ilgili olarak yapmış olduğu çalışma da bu tezi doğrulamıştır. Bu çalışma ile sapkın arkadaşlara sahip olan bireylerin daha fazla suç davranışında bulunduğu tespit edilmiştir.

Referans Grubu Teorisi (Merton, 1957) ise bireylerin davranış ve tutumlarının uygunluğunun referans gruplarına (bu grubun üyesi olsun ya da olmasın bireyin kendisi için kıyaslama olarak gördüğü insan topluluğu) göre değerlendirildiğini varsayar. Aynı geçmiş ve inancı paylaşan referans grubuna sahip olan bireylerde benzer davranış ve tutumlar görülmektedir (akt. Sadique ve Stanislas, 2016:27). Bireyler referans grubundaki kişilerin davranış ve tutumlarından etkilenmekte ve model almaktadırlar. Referans grubu dini değerlere bağlı ise bu referans grubunu model alan bireylerde aynı davranış ve tutum görülmektedir. 
Anomi teorisi ise bireylerin baskı ve gerilim ortamlarında suç işlediklerini ileri sürmektedir. Durkheim'a göre anomi kavramı sapma davranışlarını açıklamak için kullanmıştır. Modernleşmenin olduğu, nüfusun hızla arttı̆̆ı ve kültürel değerlerin zayıfladığı dolayısıyla toplumsal kontrol mekanizmasının azaldığı ortamlarda anomi meydana gelmektedir (DiCristina, 2016). Durkheim bireylerin doğası gereği kolektif bilince sahip olduklarını ifade eder. Bunu açıklamak için ise mekanik dayanışma ve organik dayanışma kavramlarını kullanmaktadır. Mekanik dayanışmaya sahip toplumlarda bireyler birbirlerine benzemektedir, doğru ve yanlış konusunda benzer inanışlar vardır ve herkes birbirini tanımaktadır. Bu ortamlarda düzeyde benzerlikler nedeniyle yüksek kontrol mekanizması bulunmaktadır. Suç işleyen birey ise toplumda büyük yaptırımlara maruz kalmaktadır. Durkheim bu tür toplumlarda baskıcı hukukun olduğunu ifade etmektedir. Organik dayanışmanın olduğu toplumlar ise nüfusun artması ve bireyler arası farklılıkların çoğalması ile meydana gelmiştir. İş bölümünün artması ortak vicdanın azalmasına neden olmuştur. Kabul edilebilir davranışların sınırları genişlemiş ve toplum katı kurallardan ve baskılardan uzaklaşmıştır. Durkheim bu toplumlarda onarıcı hukukun olduğunu ifade etmektedir. Nüfusun hızla artması ve farklı bireylerin aynı ortamı paylaşması ile bireylerin birbirini kontrol etme imkânı ve zamanı azalmıştır. Durkheim yeterli olmayan bu sosyal kontrol durumunu "anomi" kavramı ile açıklamaktadır (Özbay, 2020:115). Anomi teorisi organik dayanışmanın görüldüğü toplumlarda ortaya çıkmıştır. Sosyal bütünleşme ve sosyal değişme sosyal sapmayı açıklayan önemli kavramlardır. Durkheim hem uyumu hem de sapmayı anlamada iki temel değişken belirlemiştir. İlki gruba bağlılık/dayanışma, diğeri ise değer ve kuralcı düzenlemelerdir. Sosyal dayanışma/bütünleşmenin az olduğu durumlarda bencil intiharlar, fazla olduğu durumlarda ise elcil intiharlar görünmektedir (Özbay, 2020). Durkheim (1992) bencil intiharları bireyin içinde bulunduğu toplumla bütünleşme derecesine göre meydana geldiğini ifade etmiştir. Bireyin gruplarla ve kolektif bütün ile bağı zayıfladığında ortaya çıkmaktadır. Protestanların intihar etme olasılığının Katoliklere oranla daha yüksek olduğunu tespit etmiştir (Tubergen, Grotenhuis, Ultee, 2005:797). Katolikler ile Protestanlar arasındaki fark özgür iradeyi kabul etme derecesidir. Katolik inancında sorgulamadan kabul etme vardır, Protestan inancinda ise bireysel sorgulama vardır ve özgür irade daha fazladır. İncil ile ilgili bilgiler verilmekte ancak ona ilişkin hiçbir yorum yapılmadan bireyin kendisini sorgulaması istenmektedir (Durkheim, 1992: 152-153). Elcil intiharlarda ise birey bağlı bulunduğu gruba o kadar çok bağlanmıştır ki grup için intihar eder. Birey aşırı bireyleşme ile de yeterince bireyleşememe ile de birey intihar davranışını düşünmektedir veya yapmaktadır. Yani birey sosyal bir varlıktır ve toplumdan ayrı düşünülemez. Ayrıca insan psikolojik bir varlıktır ve kendine ait değerleri ve alışkanlıkları vardır (1992: 219). Sosyal düzenleme derecesinin az olduğu durumlarda anomik intiharlar, fazla olduğu durumlarda ise kaderci intiharlar görünmektedir. Anomik intiharlar bireylerin arzuları ve istekleri tatmin edilemez düzeye çıktığında görülmektedir. Kuralsızlık anomik intiharları meydana getirmektedir. Ani fakirleşme, aniden zengin olma, boşanma vb. durumlarda ortaya çıkar. Hızlı değişim bireylerde uyum problemine yol açacağından anomik intiharlar meydana gelir. Kaderci intiharlar ise fazla düzenlemenin olduğu toplumlarda meydana gelmektedir (Beeghley, Powers, Turner, 1995; akt. Özbay, 2020). Katı kurallar bireyde intihara neden olmaktadır. Egoist ve anomik intiharlar modern toplumlarda yaygın olarak görülmekteyken, özgecil ve kaderci intiharlar modern öncesi toplumlarda görülmektedir (DiCristina, 2016:313). Modernliğin getirdiği hızlı büyüme ve değişme bireyde anomik durumlar ortaya çıkarmıştır. Tarım ekonomisinden endüstriyel ekonomiye geçiş köklü ilişkileri ve kuralları yok etmiştir.

Ekolojik kuram Chicago Üniversitesi'nin 1930- 40'lardan itibaren toplum ekolojisi üzerine yapılan araştırmalara dayanmaktadır. Stark ve Bainbridge (1996) ahlaki topluluk tezinin ekolojik kuram üzerine inşa edildiğini ifade etmişlerdir. Ekolojik kuram artan nüfusun şehirde oluşturduğu yapı üzerine odaklanmaktadır. Burgess (1925) "yoğunlaşma bölgeleri modeli” ile şehrin yapısını izah etmeye çalışmıştır. Şehrin kalabalık bölgesinin ucuz ulaşım ve barınma imkânları nedeniyle şehrin merkezinde toplandığını, orta ya da üst sınıfa sahip olan bireylerin ise şehrin dış kısımlarına doğru yerleştiğini ifade etmiştir (akt. Bogue, 1974). Dolayısıyla şehrin merkezinde artan nüfus heterojen bir yapı oluşturarak bireylerin suç davranışına yönelmeleri için ortam hazırlamıştır. Shaw 
ve Mckay (1942) ise suç oranlarını inceleyerek suç olaylarının en fazla şehrin merkezinde toplandığını ifade etmişlerdir. Şehirde suç olgusunun dağılımı ile ilgili olarak nitel ve nicel olmak üzere birçok araştırma yapılmıştır. Araştırmacılar suçlu bireyler ile değil daha çok suçluluk oranlarının fazla olduğu bölgeler ile ilgilenmişlerdir. Yapılan birçok çalışmada elde edilen bulgular ışı ğında birçok alt kuram geliştirilmiştir. Bunlardan ilki sosyal düzensizlik teorisi diğeri ise ahlaki topluluk tezidir. Ekolojik kuramın din ile ilişkisi, 1980'li yıllarda Stark ve arkadaşlarının yapmış olduğu araştırmaya göre kurgulanmıştır (Gürler, 2010:114). Bireyin davranışları ve düşünce yapısı birinci dereceden yakın çevresi (aile, okul, akran) aracılığı ile denetlenmektedir. Ardından yakın çevresi ile birlikte resmi kanallar ile denetlenmektedirlar. Yani birey öncelikle normlar tarafından ardından ise yasalar tarafından kontrol edilmektedir. Dolayısıyla birey sürekli bir otokontrol mekanizması altındadır. Nüfusun hızlıca arttı̆̆ı, heterojen bir yapının meydana geldiği yerleşim yerlerinde bireyler birbirlerini tanımadıklarından normların etki alanı oldukça zayıflar. Sadece yasaların bireyler üzerinde etkin rol oynaması bireyleri sapma davranışından uzaklaştırmak için yeterli değildir.

\section{Ahlaki Topluluk Tezi (Moral Community Thesis)}

1930-1940 tarihleri arasında 'ahlaki topluluklar çalışması' (the study of moral communities) Şikago Üniversitesi İnsan Ekolojisi bölümü akademisyenleri arasında popüler olmuştur (Angell, 1947; Shaw and Mckay, 1942). Bu dönemde ahlaki topluluk tezi ile ilgili yapılan çalışmaların tümü kaybolmuş, Robert Angell'in 1942'deki yapmış olduğu araştırmasının kopyası olan 1972 çalışması geride kalan tek kayda değer çalışma olarak kabul edilmiştir. Ancak bu çalışmada yeterli verilerin olmayışı, totolojik olması ve ahlak ile sosyal bütünlük tam olarak tespit edilememiş olması nedeniyle referans niteliğinde olamamıştır. Ahlaki topluluk tezi 1980 yılında Stark tarafından yeniden keşfedilmiştir (akt. Stark ve Bainbridge, 1996:55).

Stark ve Hirschi'nin (1969) 'Helfire and Delinquency' adlı çalışması ahlaki topluluk tezi için merak uyandıran bir çalışma olmuştur. Bu çalışma ile elde edilen sonuçlar beklenilen düzeyde gelmeyince (dinin suç üzerinde azaltıcı etkisinin olmadığı tespit edilince) ardından farklı bölgelerde bir dizi çalışmalar yapılmıştır. Stark ve meslektaşları elde edilen sonuçları karşılaştırdığında ahlaki topluluk tezine kaynak olacak bir bilgi ortaya çıkmıştır. Yani dini faaliyetlere katılımın yüksek olduğu bölgelerde dinin suç üzerindeki etkisinin fazla olduğu, seküler toplumlarda ise dinin suç üzerindeki etkisinin az olduğu ya da hiç olmadığı sonucu elde edilmiştir. Stark ve arkadaşları (1982) elde edilen bu çelişkili bulguların sebebini incelenen topluluğun ahlaki yapısının bir sonucu olduğunu ileri sürmüşlerdi.

Stark ve arkadaşları (1982) dindarlığın bireysel bir bağlamdan ziyade sosyal bir bağlamda ele alınması gerektiğini, ekolojik alanlarda dindarlık ve sapkınlık arasında negatif ilişkinin elde edileceğini ileri sürmüşlerdir. Dindarlık ve sapkınlık arasında hiçbir ilişki bulamayan erken araştırmalar ile dindarlık ve sapkınlık arasında orta derecede ters ilişkinin varlığını gösteren sonraki araştırmalar arasındaki farkın sebebini dini ekoloji ile açıklamışlardır. Stark'ın (1982) çalışması A.B.D. Pasifik bölgesi ile Pasifik olmayan bölgelerde farklı sonuçların elde edildiğini göstermiştir. Pasifik bölgesinde anlamlı ilişki bulurken, Pasifik bölgesi dışında dindarlık ve sapkınlık arasında anlamlı ilişki bulunamamıştır (1982: 5-12). Ahlaki topluluk tezi ile ilgili olarak yapılan birçok çalışma dinin suç üzerinde etkisinin negatif ilişkili olduğunu tespit etmiştir (Benda, 1995; Johnson, Larson, Jang ve Li, 2000; Tittle ve Welch, 1983). Bazı çalışmalar ise dinin suç üzerinde zayıf ve önemsiz bir ilişkinin olduğunu tespit etmiştir (Bahr, Hawks ve Wang, 1993; Cochran, Wood ve Arneklev, 1994).

Stark (1996) tarafında popüler hale getirilen bu teori ile dindarlığın sapma üzerindeki etkisinin o kişiyi çevreleyen kültürün etki derecesine bağlı olduğu ileri sürülmüştür (Finke ve Adamczyk, 2008; Ulmer, Bader ve Gault, 2008). Stark (1996) ahlaki topluluk tezini test etmek için 1.980 lise ve 11.995 öğrenci üzerinde araştırma yapmıştır. Bu çalışma ile coğrafi bölgeye göre kilise faaliyetlerine katılma sıklığı ile kanunlarla problem yaşama arasında ilişki olup olmadığı test edilmiş ve laik pasifik bölgelerde anlamlı bir ilişki tespit edilememişti ve diğer bölgelerde ise dindarlığın suç üzerinde güçlü etkisinin olduğu tespit edilmiştir. 
Ahlaki topluluk tezine göre yüksek dindarlık düzeyine sahip bölgelerde bireylerin dini eğilimleri sürekli etkileşim yoluyla desteklenmektedir. Az sayıda dindar bireylerin bulunduğu şehir ve uluslarda dindar bireyler kendileri ile benzer düşünceye sahip birey sayısı az olacağından kendi dini normlarından yeterince etkilenmezler. Tam tersi güçlü bir ahlaki topluluk düzeyine sahip topluluklarda bireyler kendi dindarlık düzeyine bakmaksızın sapkın tutum ve davranışlar göstermezler. Nispeten düşük bireysel dindarlık seviyesine sahip bireyler güçlü ahlaki topluluklardaki bireylerin düşünce ve davranışlarından etkilenmektedir. Özetle ahlaki topluluklar herhangi bir dine inanmayanlarda dâhil olmak üzere o gruba dahil olan tüm bireylerin suç davranışlarına yönelmelerini engellemektedir (Stack ve Kposowa, 2006:328).

Stark (1996) dini bireysel bir özellik değil bir grup tarafından desteklenen bir yapıya sahip olduğunu ifade etmiştir. Din toplumdaki sosyal etkileşim için normatif bir klavuzdur. Bireysel dindarlık toplumsal dindarlık kadar önemli değildir. Tolstoy'un Anna Karenina'daki Levin karakteri ile bahsedilen şey 'ilahi hakikat tek başına bir bireye verilmez, kiliseyi sevmekle bir araya gelmiş topluluğa verilmektedir', kilise 'inançlı bireyleri bir araya getirir, en yukarıda Tanrı vardır ve kutsal ve mutlaktır (Tolstoy, 1999, akt. Sadique ve Stanislas, 2016:29). Burada birey tek başına ne kadar dindar olursa olsun bu durum onun çevresi ve içinde yaşadığ $\breve{1}_{1}$ toplum için pek de etkili değildir. Aynı şey peygamberler için de söylenebilir. Peygamberler dini öğretiyi yaymak, topluluğu temsil etmek, topluluk ile hareket etmek, topluluğa rehber olmak amaciyla görevlendirilmiş kişilerdir. Kur'an-1 Kerim'de peygamberler ile ilgili olarak “O Peygamberler, Allah'ın hidayete (doğru yola) eriştirdiği kimselerdir. Sen de onların gittiği yoldan yürü" (el-En'âm, 90) şeklinde ifade edilmektedir.

Bir ahlaki topluluğun dini homojenlik derecesi ne kadar fazla ise bireylerin tutum ve davranışları üzerindeki hâkimiyeti o derece fazladır. Hangi din olursa olsun ahlaki topluluklarda benimsenen din türü tek ve alternatif başka bir dine inanç yoksa o toplumlarda dinin bireyler üzerindeki etki derecesi daha fazla olacaktır. Farklı dinden ve mezhepten olan bireylere sahip olan ahlaki topluluklarda dinin bireyler üzerindeki etkisi düşüktür (Regnerus 2003). Son zamanlarda yapılan birçok çalışma dini etkilerin makro düzey analizlerinde bir topluluğun mezhepsel özelliklerini açıklamanın daha önemli olduğunu vurgulamışlardır. Yüzde 80'i Katoliklerden oluşan bir toplulukta dine bağlılık oranı yüzde 40'1 Evanjelik Protestan olan ve yüzde 40'1 Katolik olan toplulukta dine bağlllık oranından daha fazla olduğu görülmüştür (Ovadia ve Moore, 2010).

Stark (1982)'a göre dini bağlllı̆̆ın etkin olduğu ahlaki toplumlarda bireysel dindarlık suç/sapma ile negatif ilişkilidir. Yani dindarlık arttıkça suç/sapma davranışı azalmaktadır. Bunun tersine, dindar olmayan seküler yapıya sahip topluluklarda ise, sosyal bir norm olarak toplum tarafından kabul edilmeyen din dışı suç/sapma davranışlarının kabul edilmesi olanaklı görünmektedir.

\section{Ahlaki Topluluk Tezi Literatür Taraması}

Yukarıda da bahsedildiği gibi ahlaki topluluk tezi Durkheim ile temelleri atılmış Hirschi ve Stark'ın (1969) çalışması ile tespit edilmiş ve Stark'ın (1996) çalışması ile test edilmeye başlamıştır. Çalışmalar ilk olarak California ve Pasifik Kuzeybatı (Burkett ve White, 1974; Hirschi ve Stark, 1969), Atlanta' da (Higgins ve Albrecht, 1977), Arizona (Jensen ve Maynard, 1979), Nashville (Rhodes ve Reiss, 1970) ve Utah ve Idaho'daki Mormons üzerine yapılmıştır (Albrecht ark., 1977) (Akt. Wang ve Jang, 2018: 2). Çalışmalar çoğunlukla Yahudi ve Hristiyan geleneğine sahip olan bölgelerde özellikle A.B.D. ve Avrupa'da uygulanmış, Hristiyanlık dini üzerine odaklanmıştır (Benda ve Corwyn 2001; Regnerus, 2003; Stansfield ve Mowen, 2018). Bu bölgeler dışında yapılan araştırmalar A.B.D. ve Avrupa'da yapılan çalışmalara oranla azdır (Wang ve Jang, 2018; Groves, Newman ve Corrado, 1987).

Ahlaki topluluk tezini test eden araştırmaları üç farklı kategoride değerlendirmek mümkündür. Bunlardan ilki seküler topluluklar ile seküler olmayan topluluklarda din ile suç arasında ilişkinin olduğunu savunan araştırmalardır (Adamczyk ve Hayes, 2012; Corcoran ve diğerleri, 2012; Johnson ve diğerleri, 2000; Stack ve Kposowa, 2011; Tittle ve Welch, 1983). İkincisi seküler topluluklar ile seküler olmayan topluluklarda din ile suç arasında ilişkinin olmadığını tespit eden araştırmalar 
(Benda ve Corwyn, 2001; Junger ve Polder, 1993; Welch, Tittle ve Petee, 1991) ve üçüncüsü ise ahlaki topluluk tezi için kısmen destek bulan çalışmalardır (Richard, Bell ve Carlson, 2000; Sturgis, 2010; Wang ve Jang, 2018).

Ahlaki topluluk tezi ile ilgili olarak yapılan çalışmalar mikro ve makro düzeyli olarak sınıflandırılabilir. Mikro düzeyli çalışma yapan araştırmacılar bireysel farklılıklar üzerine odaklanmışlardır. Bu tür çalışmalar sadece dinin suç üzerindeki etkisini test etmek yerine din ve suç davranışlarının karşılıklı etkileri üzerine odaklanmışlardır. Bu kapsamda ilk mikro araştırma Empey ve Erickson (1972) A.B.D.' nin Utah bölgesinde Mormon gençler üzerine yapılmıştır. Bu bölgenin dindar olduğu düşünülmüş (yani kiliseye katılım oranlarının her 1,000 kişiden 966'sında görülmesi nedeniyle) ve analizler yapılmıştır. Elde edilen sonuçlara göre dinin suç üzerinde yüksek düzeyde negatif (caydırıcı) bir etkisinin olduğu tespit edilmiştir. Ardından Richard, Bell ve Carlson (2000) tarafından yapılan bir başka mikro çalışmada kokain, esrar ve alkol kullanan 193 kişi üzerine yapılmış ve bireysel dindarlığın sapkın davranışları engelleyip engellemediği ahlaki/dini topluluk tezi çerçevesinde ele alınmaya çalışılmıştır. Çalışma ile kiliseye katılan bireyler ile kiliseye katılmayıp kendi kendini iyileştiren gruplara katılan bireyler olmak üzere iki grup üzerine nitel araştırma yapılmıştır. Her iki grubun alkol kullanımı üzerinde negatif ilişki olduğu, kiliseye katılım ile kokain kullanımı arasında da anlamlı bir ilişki olduğu tespit edilmiştir. Kiliseye katılmayıp kendi kendini iyileştiren grup ile uyuşturucu kullanımı arasında ise herhangi bir ilişki olmadığ edilmiştir. Adamczyk ve Palmer (2008) tarafından ergenler (7. ve 12. sinıflar) üzerine toplam 2,647 kişiye anket çalışması uygulanmış dinin esrar kullanımı üzerindeki etkisi test edilmiştir. Çalışma ile dindar arkadaşa sahip olan öğrenciler ile dindar olmayan arkadaşa sahip olan öğrencilerde dinin suç üzerindeki etkisi araştırılmaya çalışılmıştır. Elde edilen sonuçlara bakıldığında dindar bireylerin esrar kullanımı üzerinde anlamlı ve negatif ilişki olduğu, dindar arkadaş oranı arttıkça esrar kullanımının azaldığı ve bireylerin ve arkadaşlarının dindarlık düzeyi ile esrar başlangıcı arasında güçlü bir ilişki olduğu tespit edilmiştir. Yine Stansfield, Moven, O'Connor, Boman (2017) cezaevindeki mahkûmlar üzerine uygulama yapmış, dini destek alan mahkûmların cezaevinden çıktıktan sonrada suç davranışını gösterip göstermediğini test edilmiştir. Bu çalışma ile dini destek eğitiminin mahkûmlar üzerinde olumlu düzeyde etkisinin olduğu, dini hizmetlerin devam etmesinin ve güçlendirilmesi gerektiği sonucuna ulaşılmıştır.

Makro düzeyli araştırmalar ahlaki topluluk tezinin ele alındığı ilk çalışmalarda görülmektedir. Araştırmacılar bireyleri tek tek değil belli bir topluluğu temsil eden bireyleri araştırma alanına dâhil etmenin daha başarılı olacağını ifade etmişlerdir. Bu tarz araştırmalar topluluk düzeyinde araştırmalardır (Chadwick ve Top, 1993; Lee ve Bartkowski, 2004; Welch, Tittle ve Petee, 1991). Dini kurumların ve üyelerinin (kilise gibi) ekolojik etkisinin değerlendirilmesi makro düzeyde yapıldığından elde edilen sonuçlar ise toplumsal düzeyde yorumlanmaktadır. Araştırmacılar bölge ve ilçe, kırsal bölge kentsel bölge veya seküler devletler ile muhafazakâr devletler düzeyinde dinin suç üzerinde etkisinin ne olduğu üzerine odaklanmıştır. Stark, Kent ve Doyle (1982) ahlaki topluluklar tezini ülke genelinde 87 farklı okulda rastgele seçtikleri ergen erkekler üzerine araştırma yapmışlardır. Bu araştırma ile okullar "ahlaki" ve "seküler" olarak sınıflandırılmışlardır. Elde edilen sonuca göre "laik" okullarda dindarlık ve sapkınlık arasındaki ilişki "ahlaki topluluk" ortamına sahip okullara göre daha zayıftır. Ek olarak, en yüksek sekülerleşme düzeyine sahip okullarda dindarlık ve sapkınlık arasındaki ilişkinin son derece zayıf olduğu tespit edilmiştir. Benzer bir çalışma yine Stark (1996) tarafından A.B.D.'de farklı coğrafi bölgelerde dindarlık ve suç ilişkisinin nasıl değiştiğini incelemek için ulusal düzeyde lise son sınıf öğrencileri üzerinde test edilmiştir. Stark seküler yapıya sahip Pasifik bölgesinde dinin suç üzerindeki etkisinin çok düşük olduğunu, pasifik bölgesi dışında ise dinin suç üzerindeki etkisinin yüksek olduğunu tespit etmiştir. Benda ve Corwyn'in (2001) Arkansas'ın Doğu kıyıları ve Güneydoğu bölgesinde dinin suç üzerinde etkisinin ne olduğu tespit etmeye çalışılmışlardır. Ellison ve diğerleri (2003) ise Güney'de yaşayan insanların Güney' de yaşamayanlara göre din ile şiddet arasında ilişki olup olmadığı test edilmiştir. Regnerus (2003) Stark'ın ahlaki topluluk tezini, ilçe ve okul düzeyinde dini bağlamlar ile bireysel düzeyde suçluluk arasındaki ilişkiyi incelemiştir. Lee ve Bartkowski (2004) tarafından yapılan bir başka çalışma da ise kırsal bölgeler ve kentsel bölgelerde dinin suç üzerindeki etkisi test edilmeye 
çalışılmıştır. Makro düzeyde din ve suç ilişkisini ahlaki topluluk tezi ile ele alan ampirik araştırmaların en büyük eksikliği coğrafi bölgelerde dini katılımdaki farklılıkları bulmaya çalışmak olmuştur (Lee, 2006; Bartkowski ve Lee, 2004). Yine ırk ve etnik kimliğin suç üzerinde analizlerinin yapılması bir diğer eksiklik olarak ifade edilebilir. Hiçbir çalışma ırk ve etnik grupların dini bağlamda suç analizlerini yapmayı başaramamıştır. Ayrıca çalışmalar dini bağlamsal etkilerin makro-yapısal anlamda suç ile nasıl etkileşime girdiğini açıllayamamıştır (Harris and Ulmer, 2013:3).

Sturgis (2008) ahlaki topluluk tezi ile ilgili olarak yapılmış 17 çalışmanın meta analizini yapmıştır. Bu 17 çalışmadan dokuzu, ahlaki topluluk hipotezini en azından kısmen destekleyen sonuçlar sunmuştur. Bu çalışmalarda farklı metodolojik çalışmalar kullanılmıştır. Metodolojik farklılıklar elde edilen sonuçların farklı yorumlanmasını sağlamıştır. Yapılan bu meta analizde çalışmaların çoğu ergenler üzerine yapılmış, yetişkinler üzerine test edilen çalışma sayısının az olduğu vurgulanmıştır. Bu çalışmalardan Toombs, Benda ve Tillmon (1999) dindarlık ve sapkınlık arasındaki ilişkiyi ergenlere kıyasla yetişkinler üzerinde daha farklı sonuçlar elde edildiğini tespit etmiştir. Welch, Tittle ve Petee (1991) örneklemlerini yetişkin Katolikler ile sınırlandırmıştır, Sturgis (2010) Amerika Birleşik Devletleri'ndeki hapishane mahkûmlarını incelemiş ve Finke ve Adamczyk (2008) bağımlı değişken olarak araştırmaya dâhil ettiği kişilerin sapkın davranışlarla ilgili gerçek deneyimleri yerine çeşitli ahlaki konulara ilişkin tutumlarını ele almıştır (akt. Sturgis ve Baller, 2012:810).

1960-1970 yılları arasında sosyologlar dinin gençlerin suç davranışları üzerinde etkisinin olup olmadığı üzerine tartışırken, günümüz çalışmaları artık ne tür suçları etkilediği üzerine odaklanmışlardır (Baier ve Wright, 2001). Ahlaki topluluk teorisine göre dinin suç üzerindeki azaltıcı etkisi suç türüne bağlıdır. Yani birdenbire meydana gelen şiddet içeren davranış (dürtüsel sapma) gibi suçlar dindarlıktan etkilenmezken, çok düşünmeyi gerektiren hırsızlık (rasyonel sapma) gibi suçlar da dindarlıktan etkilenmektedir. Beyaz yakalı suçlara yönelik tutumlar üzerine yapılan çalışmalarda ise farklı sonuçlar elde edilmiştir (Stack ve Kposowa, 2006). Finke ve Adamczyk'e (2008) göre, ulusal düzeyde dindarlığın rüşvet alma, vergi kaçakçılığı, çalıntı mal satın alma, hükümete yanlış bilgi verme ve toplu taşıma ücretlerini vermekten kaçınma gibi devletin ahlaki yaptırımı üzerinde herhangi bir etkisinin olmadığ1 tespit edilmiştir. Regnerus (2003) ise Ergen Sağlığı Ulusal Boylamsal Çalışmasını ergenler üzerine uygulamış ve Hiyerarşik Doğrusal Model (HLM) ile elde ettiği verilerin analizinde ahlaki topluluk tezine kısmi düzeyde destek bulmuştur. Araştırma ile kendini 'yeniden doğmuş Hristiyan olarak tanımlayan öğrenciler ve kilisede dini faaliyetlere katılma sıklığının hırsızlık ve küçük suçluluklar üzerindeki etkileri incelenmiştir. Elde edilen sonuçlar ise hırsızlığın kilise faaliyetlerine daha az katılan öğrenciler arasında daha yaygın olduğu, kendini 'yeniden doğmuş' Hristiyan olarak tanımlayan öğrencilerde ise daha az olduğu görülmüştür. Dinin küçük suçlar üzerinde azaltıcı etkisinin oldukça düşük olduğu görülmüştür.

Ahlaki topluluk tezini destekleyen çalışmaların sayısı fazla olsa da bazı çalışmalar ahlaki topluluk tezini desteklemeyen sonuçlar elde etmiştir. Bu çalışmaların büyük bir kısmı lise öğrencileri üzerine uygulanmıştır. Cochran ve Akers (1989) Stark'ın ahlaki topluluk tezi için yalnızca "küçük" destek bulmuşlardır. Yani toplumsal dindarlık ile bireysel dindarlığın alkol ve esrar kullanımı üzerindeki etkisi arasında önemli bir fark tespit edememişlerdir. Ancak alkol kullanımının yüksek derecede dini topluluklarda caydırıcı etkisinin olduğunu düşük dindarlık düzeyine sahip topluluklarda ise caydırıcı etkisinin olmadığını tespit etmişlerdir. Benzer şekilde, Bahr ve Hoffmann (2008) "bireysel dindarlık ile dört tür uyuşturucu kullanımı arasındaki ilişkilerin okul dindarlığından etkilenmediğini" bulmuşlardır.

Ahlaki topluluk tezini kullanarak yetişkinler üzerine yapılan bazı çalışmalarda da herhangi bir ilişkinin olmadı̆̆1 görülmüştür. Örneğin Tubergen ve diğerleri (2005) tarafından yapılmış olan çalışmada 1936'dan 1973'e kadar Hollanda'da intihar verileri kullanılmış, topluluk düzeyinde dindarlığın sadece tüm mezheplerin dindar üyelerini değil, aynı zamanda "dindar olmayanları" da intihardan koruyabileceği tespit edilmiştir. Welch, Tittle ve Petee (1991) yetişkin Katolikler üzerine araştırma yapmış sapma ile dindarlık arasında önemli bir etkileşim bulamamışlardır. 
Baier ve Wright (2001) 60 çalışmanın meta-analizinde iki soru üzerine odaklanmıştır. İlki dinin suç üzerindeki etkisinin yönü ve büyüklügüu, diğeri ise aynı çalışmalarda elde edilen sonuçların neden farklı olduğu meselesidir. Bu çalışmaların tümünde dini inanç ve davranışların bireylerin suç davranışları üzerinde olumlu bir etkisinin olmadığını, hatta dinin suç davranışları üzerinde orta derecede caydırıcı bir etkiye sahip olduğunu bulmuştur (Sadique ve Stanislas, 2016:29). Bu iki soruya cevap olarak Baier ve Wright (2001) ahlaki topluluk hipotezi, anti asketizm hipotezi ve metodolojik farklılıklar olduğunu ifade etmiştir. Yani aynı çalışmanın farklı bölgelerde farklı sonuçlar elde edilmesinin nedeni o bölgenin seküler veya dini olması ile ya da bireylerin inançlı olup olmaması ile açıklamışlardır. Araştırmada kullanılan metodolojik farklılıklar da elde edilen sonucu etkilemiştir.

Birçok araştırmacı farklı coğrafi bölgelerde yaşayan gruplar üzerinde dindarlık-sapma ilişkisinin gücünü karşılaştırarak ahlaki topluluklar hipotezini test etmiştir. Junger ve Polder (1993) ergenler üzerine yapmış oldukları araştırma ile ahlaki grup ile laik grup arasında dindarlık ve suçluluk arasında ters bir ilişkinin olduğunu tespit etmişlerdir. Ahlaki grup olarak Faslı ergenleri, laik grup olarak ise Hollandalı ergenleri örneklem olarak almışlardır. Chadwick ve Top (1993) mormonlar üzerine araştırma yapmış, ekolojik alanın dindarlık ve sapma ilişkisinin gücünü etkilemediğini bulmuşlardır. Benda ve Corwyn (2001) farklı coğrafi bölgelerde yaşayan lise öğrencileri arasındaki dindarlık-sapma ilişkisinin gücünü karşılaştırmış ve farklı coğrafi bölgeler arasında dindarlık-sapma ilişkisinin gücünün farklılık göstermediğini tespit etmiştir. Çalışma hem A.B.D.'nin doğu kıyısında hem de güneyinde yapılmıştır.

Dinin suç üzerindeki etkisini test etmek için batı dışında çok az çalışma yapılmıştır. Ahlaki topluluk tezini test etmek için ise bugüne kadar Batılı olmayan devletler üzerine çok az çalışma yapılmıştır. Dinin suç üzerindeki etkisinin olup olmadığına yönelik Türkiye'de birkaç çalışma yapılmasına karşın Ahlaki topluluk tezi kullanılarak sadece bir çalışma yapılmıştır. Demirel'in (2020) Malatya İnönü Üniversite öğrencileri üzerine yapmış olduğu bu çalışma ahlaki topluluk tezine destek sağlamamıştır. Bu çalışmada ahlaki topluluklar olarak İlahiyat Fakültesi ve seküler topluluklar olarak diğer fakülteler (Fen Edebiyat Fakültesi, İktisadi ve İdari Bilimler Fakültesi, Hukuk Fakültesi, Mühendislik Fakültesi, İletişim Fakültesi) olmak üzere rastgele seçilmiş toplam 2,005 öğrenci üzerine anket uygulanmıştır. Elde edilen sonuca göre dinin suç üzerindeki etkisinin her iki topluluk ortamlarında da eşit düzeyde olduğu (dinin suçu önlediği) tespit edilmiştir. Hatta her iki topluluk ortaminda da dinin psikoloijk taciz üzerinde azaltıcı etkisi tespit edilirken fiziki şiddet üzerinde herhangi bir etkisinin olmadığı görülmüştür.

Ahlaki topluluk tezini ele alan çalışmaların bir kısmı Tablo 1'de verilmiştir. İlk olarak çalışmaların çoğunlukla ergenler üzerinde test edildiği görülmüştür. Bunun sebebi zorunlu eğitime dahil olan bireylerin sosyal normlara daha fazla uydukları söylenebilir. Dindarlığı ölçmek için kullanılan sorular "kiliseye devam/ kiliseye üye olma" şeklindedir. Çalışmalarda elde edilen sonuçlar ise genel olarak ahlaki topluluk tezinin doğrulanması yönündedir. Ergenler üzerine yapılan çalışmaların çoğunda yetişkin örneklemlerine oranla ahlaki topluluk tezi daha az destek bulmuştur.

Tablo 1. Ahlaki Topluluk Tezi Literatür Çalışması

\begin{tabular}{|l|l|l|}
\hline Çalışmanın Yazarı/ Yazarları & Örneklem & Sonuç \\
\hline Lee ve Bartkowski (2004) & Ergen & Evet \\
\hline Adamczyk ve Palmer (2008) & Ergen & Evet \\
\hline Stark, Kent ve Doyle (1982) & Ergen & Evet \\
\hline Stark (1996) & Ergen & Evet \\
\hline Wallace ve diğerleri (2007) & Ergen & Evet \\
\hline Baier ve Wright (2001) & Karma & Evet \\
\hline Richardson, Carlson ve Bell (2000) & Yetişkin & Evet \\
\hline Corcoran ve diğerleri (2012) & Yetişkin & Evet \\
\hline Sturgis ve Baller (2012) & Yetişkin & Evet \\
\hline Lee (2006) & Yetişkin & Evet \\
\hline
\end{tabular}




\begin{tabular}{|l|l|l|}
\hline Johnson, Larson, De Li ve Jang (2000) & Yetişkin & Evet \\
\hline Ulmer, Bader ve Gault (2008) & Yetişkin & Evet \\
\hline Bainbridge (1989) & Yetişkin & Evet \\
\hline Harris ve Ulmer (2013) & Yetişkin & Evet \\
\hline Adamczyk (2012) & Yetişkin & Evet \\
\hline Adamczyk ve Hayes (2012) & Yetişkin & Evet \\
\hline Stansfield ve Mowen (2018) & Yetişkin & Evet \\
\hline Stansfield, Moven, O'Connor, Boman (2017) & Yetişkin & Evet \\
\hline Scheepers ve diğerleri (2002) & Yetişkin & Evet \\
\hline Tittle ve Welch (1983) & Yetiskin & Evet \\
\hline Empey ve Erickson (1972) & Yetişkin & Evet \\
\hline Groves, Newman ve Corrado (1987) & Yetşkin & Evet \\
\hline Stack ve Kposowa (2011) & Yetişkin & Evet \\
\hline Regnerus (2003b) & Ergen & Kismen \\
\hline Stack ve Kposowa (2006) & Yetişkin & Kismen \\
\hline Sturgis (2010) & Yetişkin & Kismen \\
\hline Wang ve Jang (2018) & Yetişkin & Kismen \\
\hline Pettersson (1991) & Yetişkin & Kismen \\
\hline Richard, Bell ve Carlson (2000) & Yetişkin & Kismen \\
\hline Cochran ve Akers (1989) & Ergen & Kısmen \\
\hline Bahr ve Hoffmann (2008) & Ergen & Hayır \\
\hline Benda ve Corwyn (2001) & Ergen & Hayır \\
\hline Bjarnason ve diğerleri (2005) & Ergen & Hayır \\
\hline Chadwick ve Top (1993) & Ergen & Hayır \\
\hline Evans ve diğerleri (1996) & Ergen & Hayır \\
\hline Junger ve Polder (1993) & Ergen & Hayır \\
\hline Welch, Tittle ve Petee (1991) & Yetişkin & Hayır \\
\hline Finke ve Adamczyk (2008) & Yetişkin & Hayır \\
\hline Tubergen ve diğerleri (2005) & Yetişkin & Hayır \\
\hline Demirel (2020) & Yetişkin & Hayır \\
\hline
\end{tabular}

\section{Sonuç ve Değerlendirme}

Birey sosyal bir varlıktır ve değerler bireyde önemli bir yere sahiptir, doğumundan ölümüne kadar toplumsal yapıların etkisi altında yaşamakta ve rol kazanmaktadır. Sahip olunan roller bireyin toplumda nasıl davranması gerektiği konusunda bilgi vermektedir. Birey öncelikle aile, okul, komşular, arkadaş grupları ile etkileşim halindedir. Ardından gelenek görenekler, toplumsal kurallar, yasal düzenlemeler ve kitle iletişim kaynakları ile etkileşim halindedir. Bu durum ahlaki topluluk tezinin ekolojik kuramla ilişkisini ortaya koymaktadır. Birey çevresi ile etkileşim halinde olduğu sürece kontrol mekanizmalarından etkilenmektedir. Sosyal kontrol kuramı bireyin hayatında önemli rol oynamaktadır. Birey sahip olduğu topluluğa bağlanmakta, faaliyetlerine katılmakta, topluluğun kurallarını yerine getirmekte ve sahip olunan inancı ortak faaliyet alanları içerisinde gerçekleştirmekte ve bağlılık yemini etmektedir. Ahlaki topluluk tezi ile ilgili olarak özetle dört temel özellik konunun anlaşılması noktasında bizim için yol gösterici olacaktır. Bunlardan ilki ahlaki topluluklar potansiyel suçlular üzerinde bir tür resmi ve gayri resmi sosyal kontrol oluşturmaya yardımcı olmaktadır. İkincisi ortak değerler ve inançlar toplumda sosyal uyumu oluşturmaktadır. Üçüncüsü bu ortak değerler ve inançlar alt gruplar tarafından paylaşıldığından kendisini bu değerleri korumaya adamış birden fazla alt grup bulunmaktadır. Son olarak ise ortak değerleri benimseyen kişiler tarafından grup dışında olanlar üzerinde baskı uygulanmaktadır (Babin 2020:4). Tüm bu özellikler dikkate alındığında ahlaki topluluk tezinin diğer kuramlarla ilişkisi ortaya çıkmaktadır. Bireyin düşünce ve davranışları topluluk tarafından şekillendiği için sosyal kontrol kuramı ile doğrudan ilişkilidir. Yine birey içinde bulunduğu grubun düşüncesinden, alışkanlıklarından etkilendiği ve sahip olduğu topluluktaki bireyleri model aldığı için sosyal öğrenme teorisi/ ayırıcı birliktelikler teorisi ile yakından ilişkilidir. Modernleşme ile gelen hızlı 
nüfus artışı ve toplumda görülen değişmeler bireylerin yalnızlaşmasına neden olmuş ve sosyal kontrolün zayıflaması sonucu anomi durumu ortaya çıkmıştır. Modernleşme bireylerin dini tutum ve davranışlarını da etkilemiş, suç/ sosyal sapma davranışlarına kolayca yönelmeleri için ortam hazırlamıştır. Ahlaki topluluk tezi, modernleşmenin etkisi altında olan ve yoğun göç alan, heterojen yapılarda ortaya çıkan sapmanın din ile ilişkisini tespit etmek için yapılan çalışmalar ile ortaya çıkmıştır. Yapılan çalışmalarda dinin suç üzerindeki etkisinin muhafazakâr ve seküler ayrımı yapılarak bireyin suç davranışlarına yönelik tutumları vurgulanmıştır. Dini aktiviteleri yerine getiren toplulukta ya da grupta yer almak, muhafazakâr çevreye sahip olmak bireyin suç davranışlarından uzaklaşmasında etkin rol oynamaktadır. Seküler toplumda yer almak ise dini etkiler az olacağından bireyin suç davranışlarına yönelmesine ortam hazırlamaktadır. Özetle içinde yaşanılan toplum bireyin suç davranışlarına yönelmede yönlendirici olmaktadır.

Ahlaki topluluk tezi literatür taraması ile yapılan çalışmalar örneklem büyüklüğü (mikro makro), örneklem türü (ergenler, yetişkinler ve karma), uygulama yeri (Kuzey-güney, PasifikPasifik olmayan) bakımından farklılıklar göstermiştir.

Elde edilen sonuçlara baktığımız da ise çalışmalarda çoğunlukla dinin suç üzerindeki etkisinin negatif düzeyde olduğu görülmüştür. Özellikle homojen toplumlarda ya da nüfusu kalabalık olmayan fazla göç almayan bölgelerde dinin suç üzerindeki etkisinin negatif düzeyde olduğu görülmüştür. Yine çok az çalışmalarda ise dinin suç üzerinde etkisinin olmadığı ya da pozitif ilişki olduğunu tespit etmiştir. Çoğu çalışma makro düzeyde yapılmıştır. Mikro boyutta yapılan çalışmalar ise daha çok mahkumlara, okullara ve yetişkin bireylere uygulanmıştır.

Türkiye'de Ahlaki topluluk tezini test eden çalışma yok denecek kadar azdır. Literatürdeki boşluğu doldurmak, Türkiye'de ahlâki topluluk tezinin ne düzeyde olduğunu araştırmak, alan çalışmalarına yeni bir bakış açısı kazandırmak oldukça önemli ve gerekli görülmektedir. Bu noktada yapılacak çalışmalar ile dinin suç üzerindeki etkileri kır-kent, dini muhafazakar şehirler ve seküler şehirler, dini zamanlar (Ramazan zamanı ve diğer zamanlar) şeklinde test edilebilir. Hatta Türkiye' de örneklem alanı genişletilerek mahkumlara, lise veya ortaokul öğrencileri üzerinde test edilebilir. Hatta analiz birimi olarak regresyon analizi dişında Hiyerarşik Doğrusal Modelleme kullanılarak topluluk etkisinin analizlere dahil edilmesi sağlanabilir.

\section{Kaynakça}

Adamczyk, Amy \& Hayes, Brittany E. (2012). Religion and Sexual Behaviors Understanding the Influence of Islamic Cultures and Religious Affiliation for Explaining Sex Outside of Marriage. American Sociological Review, 77, 723-46.

Adamczyk, A., \& Palmer, I. (2008). Religion and İnitiation into Marijuana Use: The Deterring Role of Religious Friends. Journal of Drug Issues, 38(3), 717-741.

Babin, Ted D. (2020). The Halo Effect? An Ecological Analysis of the Religion-Crime Nexus. A Dissertation Submitted in Partial Fulfillment of The Requirements For The Degree of Doctor of Philosophy in The Graduate School of The Texas Women's University. Texas.

Bahr, S. J., Hawks, R. D. and Wang, G. (1993). Family and Religious İnfluences on Adolescent Substance Abuse. Youth and Society, 24, 443-65.

Bahr, Stephen J. \& Hoffmann, John P. (2008). Religiosity, Peers, and Adolescent Drug Use. Journal of Drug Issues. 38 (3), 743-769.

Baier, Colin J., Bradley, R. and Wright, E. (2001). If You Love Me, Keep My Commandments: A MetaAnalysis of the Effect of Religion on Crime. Journal of Research in Crime and Delinquency, 38(1), 321.

Bartkowski, J. P. \& Lee, M. R. (2004). Love Thy Neighbor? Moral Communities, Civic Engagement and Juvenile Homicide in Rural Areas. Social Forces, 82(3), 1001-1035.

Benda, Brent B. (1995). "The Effect of Religion on Adolescent Delinquency Revisited". Journal of Research in Crime and Delinquency, 32, 446-466.

Benda, B. B. \& Corwyn, R. F. (1997). Religion and Delinquency: The Relationship After Considering Family and Peer Influences. Journal for the Scientific Study of Religion, 36(1), 81-92. 
Benda, Brent B. \& Corwyn, Robert F. (2001). Are the Effects of Religion on Crime Mediated, Moderated and Misrepresented by Inappropriate Measures? Journal of Social Service Research, 27, 57-86.

Bogue, Donald J. (1974). The Basic Writings of Ernest W. Burgess. Chicago: Community and Family Study Center. University of Chicago.

Bronfenbrenner, U. (1994). Ecological Models of Human Devolopment. In International Encylopedia of Education, Oxford: Elsevier.

Burkett, Steven R. (1993). Perceived Parents' Religiosity, Friends' Drinking, and Hellfire: A Panel Study of Adolescent Drinking. Review of Religious Research, 35(2), 134- 154.

Burkett, Steven R., \& Warren, Bruce O. (1987). Religiosity, peer associations, and adolescent marijuana use: A panel study of underlying causal structures. Criminology, 25(1), 109-131.

Burkett, S. R., \& White, M. (1974). Hellfire and delinquency: Another look. Journal for the Scientific Study of Religion, 13: 455-462.

Chadwick, Bruce A. \& Top, Brent L. (1993). Religiosity and Delinquency Among LDS Adolescents. Journal for the Scientific Study of Religion, 32(1), 51-67.

Cochran, J. K. \& Akers, R. L. (1989). Beyond Hellfire: An Exploration of the Variable Effects of Religiosity on Adolescent Marijuana and Alcohol Use. Journal of Research in Crime and Delinquency, 26, 198-225.

Cochran, J. K., Wood, P. K. and Arneklev, B J. (1994). Is the Religiosity Delinquency Relation Ship Spurious? A Test of Arousal and Social Control Theories. Journal of Research in Crime and Delinquency, 31, 92-123.

Corcoran, Katie E., Pettinicchio, David and Robbins, Blaine. (2012). Religion and the Acceptability of White-Collar Crime: A Cross-National Analysis. Journal for the Scientific Study of Religion, 51, 542-67.

Demirel, F. Takmaz. (2020). Din ve Sosyal Sapma: Üniversite Öğrencileri Üzerine Sosyolojik Bir Araştırma. İnönü University International Journal of Social Sciences (INIJOSS), 9(2), 468-492.

DiCristina, B. (2016). Durkheim's theory of anomie and crime: A clarification and elaboration. Australian ve New Zealand Journal of Criminology, 49(3), 311-331.

Durkheim, E. (2014); Sosyolojik Yöntemin Kuralları, (çev. Özcan Doğan), Ankara, Doğu Batı Yayınları.

Ellis, L. \& Peterson, J. (1996). Crime and Religion: An International Comparison Among Thirteen Industrial Nations. Personality and Individual Differences, 20(6), 761-768.

Ellison, Christopher G., Burr, Jeffrey A. and Patricia, McCall L. (2003). The Enduring Puzzle of Southern Homicide. Homicide Studies. 7, 326-352.

Empey, LaMar T. \& Erickson, M. L. (1972). The Provo Experiment; Evaluating Community Control of Delinquency, MA: Lexington Books.

Fichter, Joseph (2002). Sosyoloji Nedir? (Çev. Nilgün Çelebi). Yenilenmiş ve Değiştirilmiş Baskı. Ankara: Anı Yay.

Finke, Roger \& Amy Adamczyk (2008). Cross-National Moral Beliefs: The Influence of National Religious Context. Sociological Quarterly, 49, 617-52.

Güçlü, İdris \& Akbaş, Halil (2016). Suç Sosyolojisi. Seçkin Yayınları, Ankara.

Güneş, Derya K.(2018). Ergenlerin Bazı Kişilik ve Aile Özelliklerinin Suç Davranışına Etkisi, Doktora Tezi, Ankara Yıldırım Beyazıt Üniversitesi Sağlık Bilimleri Enstitüsü, Ankara.

Gürler, A. (2010). Din ve Suç (Hükümlüler Üzerine Uygulamalı Bir Araştırma), Doktora Tezi, Süleyman Demirel Üniversitesi Sosyal Bilimler Enstitüsü, Isparta.

Groves, W. B., Newman, G. and Corrado, C. (1987). Islam, Modernization and Crime: A Test of the Religious Ecology Thesis. Journal of Criminal Justice, 15, 495-503.

Higgins, Paul C. \& Gary L. Albrecht. (1977). Hellfire and Delinquency Revisited. Social Forces, 55, 952-58.

Hirschi, T \& Stark, R. (1969). Hellfire and Delinquency. Social Problems, 17, 202-13.

İçli, Tülin G. (2007). Kriminoloji (7.Baskı), Seçkin Yayınları, Ankara. 
Jensen, Gary F. \& Erickson, Maynard L. (1979). The Religious Factor and Delinquency: Another Look at the Hellfire Hypothesis, (Eds. Robert Wuthnow), The Religious Dimension: New Directions in Quantitative Research. New York: Academic Press.

Johnson, B. R., Larson, D. B., De Li, S. and Jang, S. J. (2000). Escaping From The Crime Of İnner Cities: Church Attendance and Religious Salience Among Disadvantaged Youth. Justice Quarterly, 17(2), 377-391.

Junger, Marianne \& Polder, Wim (1993). Religiosity, Religious Climate and Delinquency Among Ethnic Groups in the Netherlands. British Journal of Criminology, 33(3), 416-35.

Kandemir, Fatih. (2018). Ekolojik Kuram Bağlamında Dinî Gelişim Psikolojisi (Religious Development Psychology in the Context of Ecological Theory). Cumhuriyet Illahiyat DergisiCumhuriyet Theology Journal, 22(3), 1433-1456.

Lee, M. R. (2006). The Religious İnstitutional Base and Violent Crime in Rural Areas. Journal for the Scientific Study of Religion, 45(3), 309-324.

Ovadia, S. \& Moore, L. M. (2010). Decomposing the Moral Community: Religious Contexts and Teen Childbearing. City and Community, 9(3), 320-334.

Özbay, Özden. (2020). Suç Teorilerine Giriş, Talebe Ders Kitapları Yayınları Serisi, Türk Eğitim Yayınlar1 (E Kitap).

Özbay, Özden. (2021). Nitel Araştırma Sözlüğ̈̈, Talebe Ders Kitapları Yayınları Serisi, Türk Eğitim Yayınları (E Kitap).

Regnerus, M. D. (2003). Moral Communities and Adolescent Delinquency: Religious Contexts and Community Social Control. The Sociological Quarterly, 44(4), 523-554.

Richard, Alan J., David C. Bell, and Carlson, Jerry W. (2000). Individual Religiosity, Moral Community, and Drug User Treatment. Journal for the Scientific Study of Religion, 39(2), 240.

Sadique, K. \& Stanislas, P. (Eds.). (2016). Religion, faith and crime: Theories, identities and issues. Springer.

Shaw, C. R., \& McKay, H. D. (1942). Juvenile Delinquency and Urban Areas. University of Chicago Press.

Stansfield, Richard Moven, O'Connor, Thomas J., Thomas and Boman, John H. (2017). The Role of Religious Support in Reentry: Evidence From The SVORI Data. Journal of Research in Crime and Delinquency, 54(1), 111-145.

Stack, S. Kposowa \& Augustine J. (2006). The Effect of Religiosity on Tax Fraud Acceptability: A Cross-National Analysis. Journal for the Scientific Study of Religion, 45(3), 325-351.

Stack, S. Kposowa \& Augustine, J. (2011). Religion and Suicide Acceptability: A Cross-National Analysis. Journal for the Scientific Study of Religion, 50, 289-306.

Stark, Rodney. (1996). Religion as Context: Hellfire and Delinquency One More Time. Sociology of Religion, 57(2), 163.

Stark, Rodney \& Bainbridge, William S. (1996). Religion, Deviance, and Social Control. New York: Routled.

Stark, Rodney, Kent, Lori and Doyle, Daniel P., (1982). Religion and Delinquency: The Ecology of a "Lost" Relationship. Journal of Research in Crime and Delinquency, 19(1), 4-24.

Sturgis, Paul W. (2008). Faith Behind Bars: The Social Ecology of Religion and Deviance in the Penitentiary, Doktora Dissertation, University of Missouri.

Sturgis, Paul W. (2010). Faith Behind Bars: An Explicit Test of the Moral Community Hypothesis in the Correctional Environment. Journal of Offender Rehabilitation, 49(5), 342-6.

Sturgis, P. W. \& Baller, R. D. (2012). Religiosity and deviance: An examination of the moral community and antiasceticism hypotheses among US adults. Journal For the Scientific Study of Religion, 51(4), 809-820.

Tittle, Charles R. \& Welch, Michael R. (1983). Religiosity and Deviance: Toward a Contingency Theory of Constraining Effects. Social Forces, 61, 653-82.

Toombs, Nancy J., Benda, Brent B. and Tilmon, Randy D. (1999). A Developmentally Anchored Conceptual Model of Drug Use Tested Among Adult Boot Camp İnmates. Journal of Offender Rehabilitation, 29(1/2), 49 
Tubergen, F. Van, Grotenhuis, M. and Ultee, W. (2005). Denomination, Religious Context, and Suicide: Neo-Durkheimian Multilevel Explanations Tested With İndividual and Contextual Data. American Journal of Sociology, 111(3), 797-823.

Turner, Carol J. \& Willis, Robert J. (1979). The Relationship Between Self-Reported Religiosity and Drug Use by College Students. Journal of Drug Education, 9(1), 67- 78.

Ulmer, J. T., Bader, C. and Gault, M. (2008). Do Moral Communities Play a Role in Criminal Sentencing? Evidence From Pennsylvania. Sociological Quarterly, 49(4), 737-768.

Ulmer, Jeffery T. \& Harris, Casey T. (2013). Race and the Religious Contexts of Violence: Linking Religion and White, Black, and Latino Violent Crime. Sociol Q. 54(4), 610-646. doi:10.1111/tsq.12034.

Wang, X. \& Jang, S. (2018). The Effects of Provincial and Individual Religiosity on Deviance in China: A Multilevel Modeling Test of the Moral Community Thesis. Religions, 9(202), 3.

Welch, M. R., Tittle, C. R. and Petee, T. (1991). Religion and Deviance Among Adult Catholics: A Test of the "Moral Communities" Hypothesis. Journal for the Scientific Study of Religion, 30(2), 159. Yücel, M. T. (2004). Kriminoloji (1.Baskı), İstanbul: Umut Vakfı Yayınları.

\section{Extended Abstract}

\section{Aim and Scope}

Throughout history, there have been many studies on religion and crime, especially at the sociological level. Researches have been mostly tested using social control, social learning, rational choice theory, control theory. However, the ecological study of the social impact of religion on criminal behavior has been relatively neglected by academics. According to the moral community thesis, individuals commit less or no crime in conservative societies than in secular societies. Individual front towards criminal / social deviation behaviors emerges with the positive or negative effect of the environment on the individual's behavior.

There are hardly any studies on the moral community thesis in Turkey. Studies revealing the effect of religion on crime have mostly been applied in the United States, Europe and China, and different results have been obtained. In Turkey, there have been many studies that reveal the effect of religion on crime but only one study has been conducted to test the moral community thesis. The aim of this study is to emphasize what the moral community thesis is and its place in the literature. After that, it is to bring a new perspective to the studies to be done on the religion-crime relationship in Turkey. In this study, traditional literature review was used and focused on the studies and the findings obtained. The results obtained revealed that the sample was mostly applied to adults and the moral community thesis was supported. It has been observed that studies in this field have increased in recent years.

\section{Conclusion}

Studies have emphasized the individual's attitudes towards criminal behavior by making a distinction between conservative and secular, the effect of religion on crime. Being in the community or group that performs religious activities and having a conservative environment play an active role in keeping the individual away from criminal behavior. Taking part in a secular society, on the other hand, prepares an environment for the individual to turn to criminal behavior, as religious effects will be less. In summary, the society in which one lives is directing the individual towards criminal behavior. Studies conducted with the moral community thesis literature review showed differences in terms of sample size (micro macro), sample type (adolescents, adults and mixed), application location (North-south, Pacific-non-Pacific). When we look at the results obtained, it was seen in the studies that the effect of religion on crime was mostly negative. It has been observed that the effect of religion on crime is at a negative level, especially in homogeneous societies or in regions with a small population that do not receive much migration. Again, few studies have found that religion has no effect on crime or has a positive relationship. Most studies have been done at macro level. Micro-scale studies were mostly applied to prisoners, schools and adults. 